\title{
O08 - Increased early life Transepidermal Water Loss (TEWL) values can predate atopic dermatitis in asymptomatic infants: results from the BASELINE study
}

Maeve Kelleher ${ }^{1 *}$, Audrey Galvin Dunn ${ }^{1}$, Alan Irvine ${ }^{2}$, Hazel Smith', O'B Jonathan Hourihane ${ }^{1}$

From 3rd Pediatric Allergy and Asthma Meeting (PAAM)

Athens, Greece. 17-19 October 2013

\section{Background}

We sought to ascertain whether a non-invasive measurement of skin barrier function at birth could predict the development of Atopic Dermatitis in asymptomatic infants enrolled in an unselected prospective birth cohort.

\section{Method}

1903 infants were enrolled on the Cork BASELINE Birth Cohort study from July 2009 to Oct 2011. Infants had Transepidermal water loss (TEWL) measured at birth, 2 and 6 months. AD was assessed at 6 and 12 months, using the UK Diagnostic Criteria. Severity was assessed by SCORAD method at 6 months and by both SCORAD and Nottingham Severity Score (NSS) at 12 months.

\section{Results}

The point prevalence of $\mathrm{AD}$ in our cohort was $18.7 \%$ $(299 / 1597)$ at 6 months and $15.52 \%(232 / 1494)$ at 12 months. TEWL was lowest at birth, with mean reading 7.32 gwater $/ \mathrm{m} 2 / \mathrm{hr}( \pm 3.33$ gwater $/ \mathrm{m} 2 / \mathrm{hr})$. It rose between birth and 2 months, mean 10.97 gwater $/ \mathrm{m} 2 / \mathrm{hr}$ $( \pm 7.98$ gwater $/ \mathrm{m} 2 / \mathrm{hr})$ where it plateaued at 6 months with mean reading 10.71 gwater $/ \mathrm{m} 2 / \mathrm{hr}( \pm 7.10$ gwater/ $\mathrm{m} 2 / \mathrm{hr})$. A raised TEWL at 2 months was independently predictive of Atopic dermatitis at 12 months, but not 6 months when controlling for mode of recruitment, parental atopy and presence of $\mathrm{AD}$.

\section{Conclusion}

Increased Transepidermal water loss is a non invasive signal for skin barrier impairment seen at 2 months in

University College Cork, Cork, Ireland

Full list of author information is available at the end of the article asymptomatic infants prior to clinical appearance of Atopic Dermatitis. This signal is not seen at birth. This finding has implications for the possible prevention of $\mathrm{AD}$ if sufficient intervention was put in place to maintain the skin barrier, prior to the appearance of AD.

Authors' details

${ }^{1}$ University College Cork, Cork, Ireland. ${ }^{2}$ Trinity College Dublin, Dublin, Ireland.

Published: 28 February 2014

doi:10.1186/2045-7022-4-S1-08

Cite this article as: Kelleher et al: 008 - Increased early life

Transepidermal Water Loss (TEWL) values can predate atopic dermatitis in asymptomatic infants: results from the BASELINE study. Clinical and Translational Allergy 2014 4(Suppl 1):08.

Submit your next manuscript to BioMed Central and take full advantage of:

- Convenient online submission

- Thorough peer review

- No space constraints or color figure charges

- Immediate publication on acceptance

- Inclusion in PubMed, CAS, Scopus and Google Scholar

- Research which is freely available for redistribution

Submit your manuscript at www.biomedcentral.com/submit 